\title{
Damage Level of Cydalima perspectalis (Lepidoptera: Crambidae) on Naturally Growing and Ornamental Box Populations in Artvin, Turkey
}

\author{
Hazan ALKAN AKINCI ${ }^{{ }^{*}} \mathbb{\oplus}$, Oğuz KURDOĞLU²® \\ ${ }^{1}$ Artvin Çoruh University, Faculty of Forestry, Artvin, TURKEY \\ ${ }^{2}$ Karadeniz Technical University, Faculty of Forestry, Trabzon, TURKEY \\ *Corresponding Author: hazan.akinci@artvin.edu.tr
}

Received Date: 29.11.2018

Accepted Date: 25.03.2019

\begin{abstract}
Aim of study: The box tree moth, Cydalima perspectalis (Lepidoptera: Crambidae), is an important alien invasive species on box, Buxus sempervirens, in Turkey. It was first detected in 2011 in Istanbul. It is a native pest of box plants in Asia. Its first discovery in Europe has been made in 2007 in Germany. Since then it has been successfully established in various ecosystems in Europe. Caterpillars feed on box leaves and cause severe defoliation and tree deaths. In this study, damage level and defoliation percentage were investigated on ornamental and naturally growing box plants.

Area of study: Box plants were sampled in Artvin in the Eastern Black Sea Region of Turkey.

Material and Method: A total of 90 box plants that were either naturally growing or ornamental box plants were sampled

Main results: Majority of the naturally growing box plants (63.4\%) had strong and very strong damages, and $71.4 \%$ of the ornamental box plants had middle and strong damage levels.

Research highlights: Of the all observed plants, $53.4 \%$ had $40-100 \%$ defoliation and $25 \%$ of these plants did not recover.

Keywords: Box Tree Moth, Buxus sempervirens, Defoliation, Alien Species

\section{Cydalima perspectalis (Lepidoptera: Crambidae)'in Artvin,}

\section{Türkiye'deki Doğal Olarak Yetişen ve Süs Bitkisi Olarak Yetiştirilen Şimşir Populasyonlarındaki Zarar Seviyesi}

$\ddot{O} \mathbf{z}$

Çalışmanın Amacı: Şimşir kelebeği, Cydalima perspectalis (Lepidoptera: Crambidae), Türkiye'de, şimşirin, Buxus sempervirens, önemli bir yabanc1 istilacı türüdür. İlk olarak 2011'de İstanbul'da tespit edilmiştir. Asya'daki şimşirlerin doğal bir türüdür. Avrupa'da ilk olarak 2007 yllında Almanya'da tespit edilmiştir. Tespit edildiği günden buyana Avrupa'da çeşitli ekosistemlere başarılı bir şekilde yerleşmiştir. Trrtıllar şimşir yapraklarıyla beslenir ve şiddetli yaprak kaybına ve ağaç ölümlerine neden olur. $\mathrm{Bu}$ çalışmada, süs bitkisi olarak yetiştirilen ve doğal olarak yetişen şimşirlerdeki zarar seviyesi ve yaprak kaybı oranı araştırılmıştır.

Çalışma Alanı: Türkiye'nin Doğu Karadeniz Bölgesindeki Artvin'de şimşir bitkileri örneklenmiştir.

Materyal ve Yöntem: Doğal olarak yetişen ya da süs bitkisi olarak yetiştirilen toplam 90 şimşir örneklenmiştir.

Temel Sonuçlar: Doğal olarak yetişen şimşirlerin çoğunluğu $(\% 63,4)$ kuvvetli ve çok kuvvetli zarar görmüştür, süs bitkisi olarak yetiştirilen şimşirlerin $\% 71,4$ 'ü ise orta düzeyde ve kuvvetli zarar görmüştür.

Araştırma vurgularr: İncelenen tüm bitkilerin \%53,4'ünde \%40-\%100 yaprak kaybı yaşanmış ve bunların \%25'i zararı atlatamamıştır.

Anahtar Kelimeler: Şimşir Kelebeği, Buxus sempervirens, Yaprak Kaybı, Yabancı Tür 


\section{Introduction}

The box tree moth (BTM) Cydalima perspectalis (Walker, 1859) (Lepidoptera: Crambidae) is an alien invasive species in Europe including Turkey, and causes severe damages to box trees (Buxus spp.) in gardens, natural and semi-natural box tree forests (Krüger, 2008; Feldtrauer, Feldtrauer \& Brua, 2009; Leuthardt, Billen \& Baur, 2010; Straten and Muus, 2010; Hizal, Köse, Yesil \& Kaynar, 2012; Kenis, Nacambo, Leuthardt, Di Domenico \& Haye, 2013). BTM is a native species of East Asia (Inoue, Sugi, Kuroko, Moriuti \& Kawabe, 1982). In Europe, the species was first recorded in 2007 from southwest Germany and the Netherlands (Krüger, 2008, Straten \& Muus, 2010). Since then it has spread throughout in various ecosystems in Europe (Feldtrauer et al., 2009; Leuthardt et al., 2010; Straten \& Muus, 2010; Sáfián and Horváth, 2011; Seljak, 2012; Kenis et al., 2013; Fora and Poşta, 2015). In Turkey, BTM was first reported from İstanbul (Hizal et al., 2012), then found in Düzce (Öztürk, Akbulut \& Yüksel, 2016), Artvin and Bartın (Anonymous, 2018; Toper-Kaygin and Taşdeler, 2018).

BTM feeds on Buxus sempervirens L. and B. microphylla Sieb. \& Zucc. in Europe (Leuthardt and Baur, 2013). It is reported to feed on B. sinica (Rehder \& E.H.Wilson) M.Cheng and feed on other Buxus spp. in China and Japan (Wan et al., 2014). Euonymus japonicus Thunb. and Ilex purpurea Hassk. are also mentioned as host plants in Asia (Straten \& Muus, 2010). In Turkey, the species has been reported only on B. sempervirens to date (Anonymous, 2018; Toper Kaygın \& Taşdeler, 2018).

Formerly, natural $B$. sempervirens populations in the region have been devastated by boxwood blight Cylindrocladium buxicola Henricot (Henricot \& Culham 2002) disease. This fungal pathogen was first noted in the end of 2011, in Trabzon and Artvin provinces. Devastating effects were reported in affected areas. Approximately $90 \%$ of the boxwood plants have been completely defoliated by this disease (Lehtijärvi, Doğmuş-Lehtijärvi \& Oskay, 2014; 2017).

Buxus sempervirens has ecological, economic and cultural value for the region.
There are remarkable stands or wild populations in or close to protected areas. Box plants are used in gardens and parks as design plants. In addition, its hardwood is used in handcrafting industry, and fresh branches in floristry.

Foresters and the local community have concerns about the BTM's potential threat on natural $B$. sempervirens populations. Today distribution range of the $B$. sempervirens and BTM overlaps in Turkey. BTM has been recorded to devastate large areas that are larger than 100 ha of natural box forests during one single summer generation in Switzerland (Leuthardt and Ramin, 2011). Similar records have been notified from Russian Caucasus (Gninenko, Shiryaeva \& Shurov, 2014). Caterpillars feed on the leaves of box trees and cause severe defoliation and eventually the death of trees. Defoliation and rapid death of the box trees increase exposure to sunlight in these destroyed ecosystems and cause a change of the ground covering vegetation (John and Schumacher, 2013). In Turkey, the effects of the moth on the survival of natural box populations and functions of forest ecosystems in the devastated large areas are of great concern. In this study, we aimed to evaluate the damage of BTM on sampled box plants and discuss damage level and the survival of natural box plants after attack.

\section{Materials and Methods}

The study was conducted from March to October in 2018, in Artvin in the Eastern Black Sea region of Turkey. A total of 90 box plants that were either naturally growing or ornamental box plants were sampled.

\section{Buxus sempervirens L.}

Buxus sempervirens $\mathrm{L}$. has a wide distribution range in Euro-Siberian flora region. It basically grows in the understory of broad leaved forests along river valleys. In the distribution range, there are Picea orientalis (L.) Link. and Alnus glutinosa subsp. barbata (C. A. Mey.) Yalt. few in number at the canopy, and Sambucus nigra L. and Ilex colchica Poj. at the understory layer, and Dryopteris Adans., Pteridium Gled. ex Scop., Galium L. at the herbaceous layer together with box plants (Aksoy, 1998). B. sempervirens establishes pure forest stands at 
$900 \mathrm{~m}$ a.s. 1 . and $1500 \mathrm{~m}$ a.s.l at Firtına Valley (Figure 1a) in the Eastern Black Sea region (Aksoy, 1998). These distribution areas are located in Kaçkar Mountains National Park. In addition to these stands, natural populations of wild B. sempervirens in Hatila Valley National Park, Klaskür Valley, Kamilet Valley,

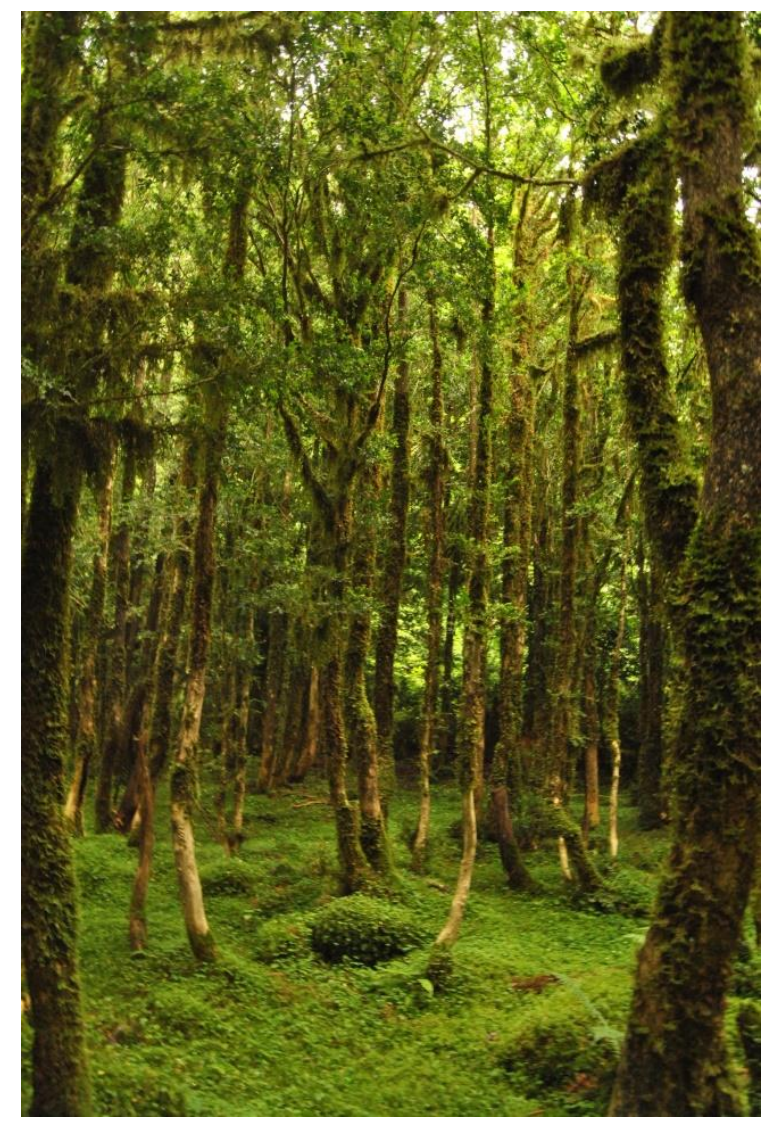

Boxwood Gene Protection Forest and Galyan Valley in the Eastern Black Sea region are remarkable. Diameter and height of the box plants can reach $8-35 \mathrm{~cm}$ and $2-10 \mathrm{~m}$, respectively (Aksoy, 1998). All the mentioned sites have faced BTM damage in the region (Figure 1b).

In Turkey, $B$. sempervirens and B. balearica Lam. are the native box species (Yaltırık and Efe, 2000).

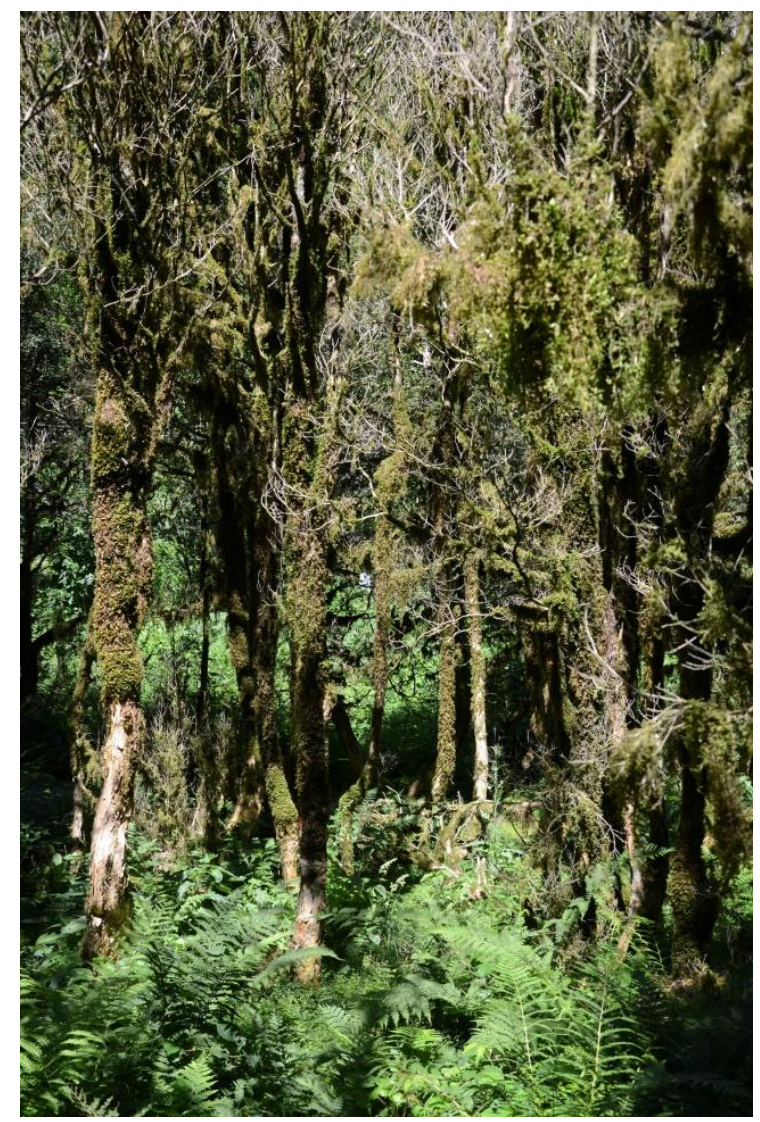

Figure 1. Natural Buxus sempervirens stand at Firtına Valley located in Kaçkar Mountains National Park, a. stand scene before Cydalima perspectalis damage, b. stand scene after the damage (Photos by Oğuz Kurdoğlu)

\section{Field Survey}

Naturally growing and ornamental box plants were sampled at wild habitats along Çoruh River from Artvin to Borçka at dispersed habitat and at the campus of Artvin Çoruh University, respectively. There were 41 naturally growing and 49 ornamental box plants. BTM larval feeding activity was first recorded at 20 March 2018 in Artvin Çoruh University Campus. After this date, naturally growing box plants and ornamental box plants have been observered every 10 days and 3-5 days until late October, respectively.

\section{Observations on the Damage Level}

Defoliation percentage and damage level on the sampled box plants were made by visual assessments following the work of Fora $\&$ Poşta (2015). There were 5 classes both for defoliation percentage and damage level. Defoliation percentages $(\%)$ were classified as $0,1-20, \quad 21-40, \quad 41-60$ and $>60$, and 
corresponding damage levels were $0,1,2,3$ and 4 , respectively. The significance of damage was categorized as follows: undamaged, weak, middle, strong and very strong (Fora \& Poşta, 2015).

Defoliation percentage for every attacked box plant was recorded on every observation date. There were more or less recovery of the leaves on the damaged box plants until the next generation's caterpillars were observed. By the end of the October, total recovery of the leaves were recorded based on visual assesments as done for defoliation percentages before.

\section{Results and Discussion}

The first larval feeding activity was recorded on ornamental plants on March 20, 2018. Caterpillars either massively ate or skeletonized the leaves. Caterpillars were protected by loose webbing (Figure 2a, b, c).

Pupation occurred in the foliage and BTM pupae were well hidden between leaves and hard to see (Figure 2d). As for the adults, the most common variant of the species that has mostly white wings with a dark brown band at the outer margin were observed (Figure 2e). Newly hatched young caterpillars fed only at the underside of the leaves (Figure 2f).

The damage of BTM was observed $95.6 \%$ of the box plants examined. Defoliation percentages ranged between $10 \%$ and $100 \%$. Of the 90 plants, $4.4 \%$ were undamaged, and $13.3 \%, 28.9 \%, 34.4 \%$ and $19.0 \%$ of the rest had weak, middle, strong and very strong damages, respectively. According to the defoliation percentages, majority of the naturally growing box plants $(63.4 \%)$ had strong and very strong damages, and $71.4 \%$ of the ornamental box plants had middle and strong damages (Table 1).

Fora \& Poşta (2015) studied at parks and gardens located in both urban and rural places. They reported that $19.35 \%$ of the individuals did not defoliate, $50.00 \%, 8.06 \%, 6.45 \%$, $16.14 \%$ had weak, middle, strong and very strong damages, respectively. The percentage of middle, strong and very strong damaged plants in our study are higher than Fora \& Poşta (2015)'s results. When we compare our results that are related to naturally growing box plants at wild habitats, our damage results are again higher than Fora \& Poşta (2015)'s results at the formerly mentioned damage levels. For the ornamental box plants in our study, our results are higher at middle and strong damage levels than Fora \& Poşta (2015)'s results. Apparently BTM has well established in B. sempervirens growing areas both in gardens and wild habitats and damage box plants seriously in the Eastern Black Sea Region of Turkey. And their damage to box plants could be higher than some invaded countries in Europe.

Box plants that had weak and middle damage and lost their foliage up to $40 \%$ fully recovered after the BTM larval feeding. Plants with $41-60 \%$ defoliation recovered 50 to $75 \%$ of the defoliated leaves. There was $25 \%$ recovery of the leaves in 5 of the box plants that had very strong damage and faced more than $60 \%$ defoliation during larval feeding. No recoveries were observed in fully defoliated 12 box plants (Table 2, Figure 3 ).

The overlapping distribution of BTM and naturally growing box tree populations have also been reported from north-western Switzerland and south-western Germany (John \& Schumacher, 2013). BTM caused more than $90 \%$ defoliation of all box trees in the Nature Reserve of Grenzach-Whylen where there is largest box tree forest in Germany. And $27 \%$ of the box plants could not recover (Kenis et al., 2013). In the current study, $95.6 \%$ of examined box plants were defoliated in different degrees by BTM. $53.4 \%$ of the all observed plants had strong and very strong damage and lost more than $40 \%$ of their foliage. Of these that had strong and very strong damages, $25 \%$ could not recover. 

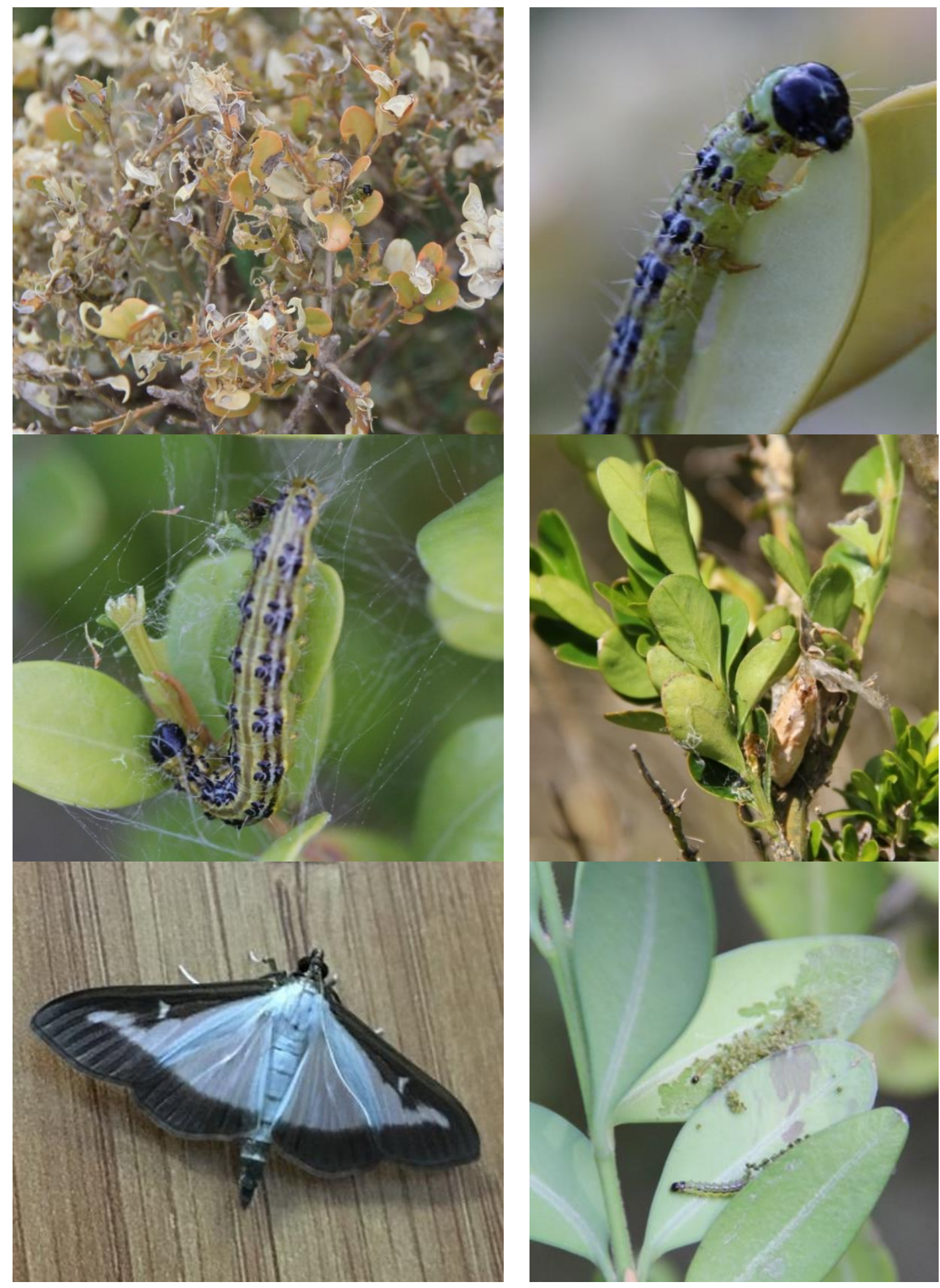

Figure 2. a. skeletonized leaves, b. late instar larva feeding on leaves, c. loose webbing around larva, d. pupa in the foliage, e. adult, f. young caterpillars feeding at the underside of the leaves (Photos by Hazan Alkan Akınc1) 
Table 1. Defoliation percentage and damage level of BTM at the studied sites

\begin{tabular}{cccccr}
\hline \multirow{2}{*}{$\begin{array}{c}\text { Defoliation } \\
(\%)\end{array}$} & Damage & Damage & Number of & \multicolumn{2}{c}{ Number of box plants } \\
\cline { 5 - 6 } & level & significance & box plants & $\begin{array}{c}\text { naturally } \\
\text { growing }\end{array}$ & ornamental \\
\hline 0 & 0 & undamaged & $4(4.4)^{*}$ & $2(4.9)$ & $2(4.1)$ \\
\hline $1-20$ & 1 & weak & $12(13.3)$ & $7(17.1)$ & $5(10.2)$ \\
\hline $21-40$ & 2 & middle & $26(28.9)$ & $6(14.6)$ & $20(40.8)$ \\
\hline $41-60$ & 3 & strong & $31(34.4)$ & $16(39.0)$ & $15(30.6)$ \\
\hline$>60$ & 4 & very strong & $17(19.0)$ & $10(24.4)$ & $7(14.3)$ \\
\hline \multicolumn{2}{l}{ Total number of box plants } & 90 & 41 & 49 \\
\hline
\end{tabular}

${ }^{*}$ Numbers in brackets show the percentage (\%) of box plants

Table 2. Recovery status of the leaves after BTM damage

\begin{tabular}{|c|c|c|c|c|c|}
\hline \multirow{2}{*}{$\begin{array}{l}\text { Defoliation } \\
\qquad(\%)\end{array}$} & \multirow{2}{*}{$\begin{array}{c}\text { Damage } \\
\text { level }\end{array}$} & \multirow{2}{*}{$\begin{array}{c}\text { Damage } \\
\text { significance }\end{array}$} & \multirow{2}{*}{$\begin{array}{l}\text { Number of } \\
\text { box plants }\end{array}$} & \multicolumn{2}{|c|}{$\begin{array}{l}\text { Recovery of the leaves after BTM } \\
\text { damage }\end{array}$} \\
\hline & & & & recovered leaves & no recovery \\
\hline 0 & 0 & undamaged & $4(4.4)^{*}$ & & \\
\hline $1-20$ & 1 & weak & $12(13.3)$ & fully recovered & \\
\hline $21-40$ & 2 & middle & $26(28.9)$ & fully recovered & \\
\hline $41-60$ & 3 & strong & $31(34.4)$ & $\begin{array}{l}1 / 2 \text { and } 3 / 4 \text { of the } \\
\text { leaves recovered }\end{array}$ & \\
\hline$>60$ & 4 & very strong & $17(19.0)$ & $\begin{array}{l}1 / 4 \text { of the leaves } \\
\text { recovered in } 5 \\
\text { plants }\end{array}$ & $\begin{array}{l}\text { no recovery } \\
\text { in } 12 \text { plants }\end{array}$ \\
\hline
\end{tabular}

\footnotetext{
* Numbers in brackets show the percentage (\%) of box plants
}

In conclusion, only $4.4 \%$ of studied box trees were undamaged, $42.2 \%$ had weak or middle damages. These results suggest that BTM has a quite strong harmful effect on box trees in the study site. Tree deaths at the understory of forests in BTM's distribution range will inevitably affect functioning of forest ecosystems. John \& Schumacher (2013) already report the change of the ground covering vegetation due to increased exposure to sunlight after tree deaths. Repeated attacks of BTM threaten the survival of $B$. sempervirens in the region. So far, there is no invasion report

on B. balearica in Turkey. But possible arrival of the moth to the distribution area of
B. balearica areas may have severe consequences and destroy this rare species.

Manual removal of the caterpillars every 2 days in parks and gardens (Artvin Çoruh University campus in our case) may be effective against BTM. But in forests additional control measures are needed. As the existing prevention and control measures are not enough to overcome the dispersal and damage of BTM, further studies should focus on the biological control of the moth for sustainable solution such achieved in other important pests (Clausen, 1978; Grégoire, 1988; Alkan-Akıncı, Eroğlu \& Özcan, 2010; Fischbein and Corley, 2015). 

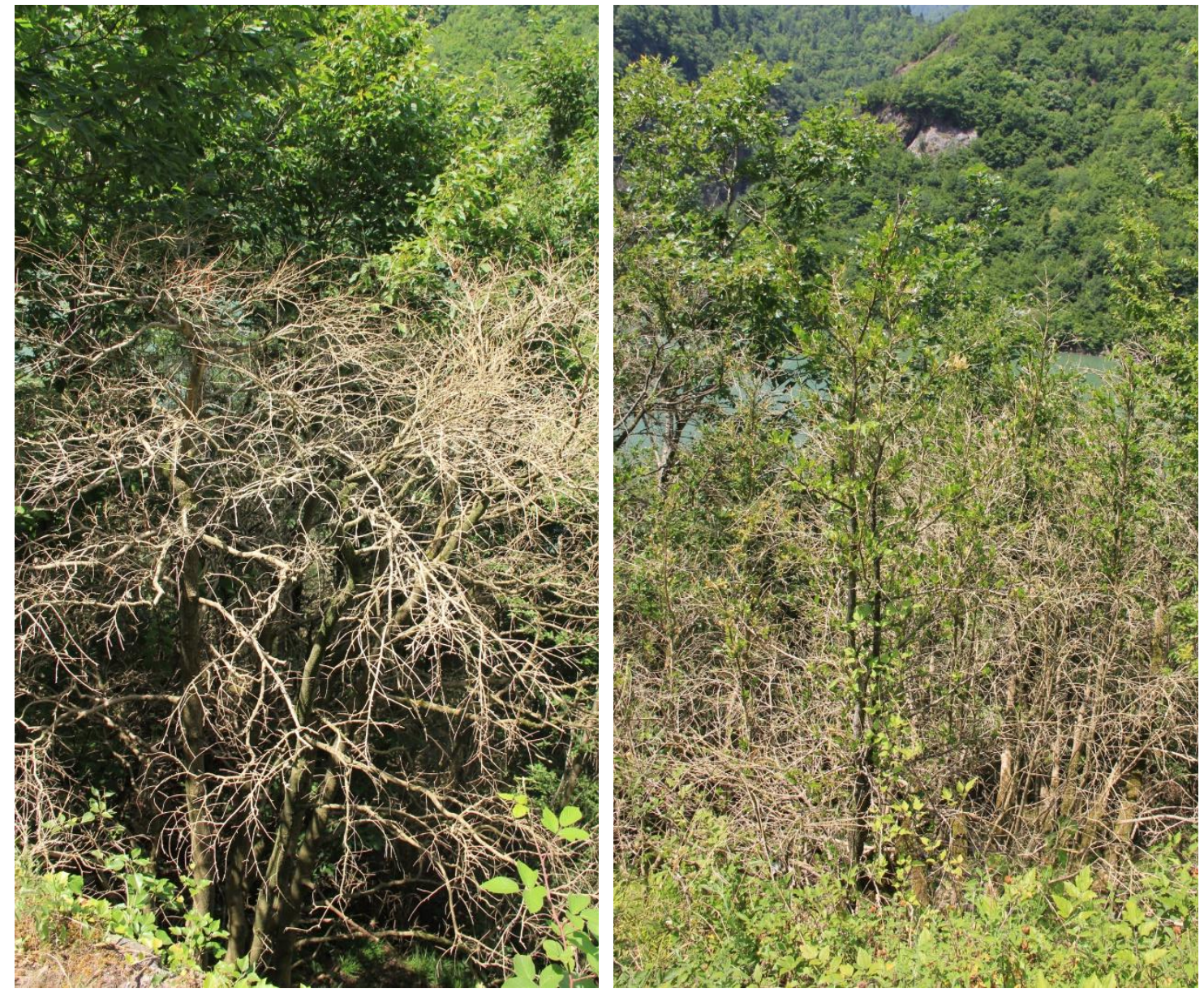

Figure 3. Naturally growing box plants that were fully defoliated and could not recover (Photos by Hazan Alkan Akıncı)

\section{References}

Aksoy, N. (1998). Expeditions to the Box (Buxus sempervirens) Forest at Furtına Catchment Area (Çamlıhemşin, Rize). The Karaca Arboretum Magazine, 4(3), 97-108.

Alkan-Akınc1, H., Eroğlu, M. \& Özcan, G.E. (2010). Ladin Ormanlarımızda Rhizophagus grandis (Gyllenhal)'in Dendroctonus micans (Kugelann) Popülasyonlarına Yerleşmesi ve Predatörün Kolonizasyon Düzeyleri. Kastamonu Üniversitesi Orman Fakültesi Dergisi, 10(2), 137-146.

Anonymous, (2018). Şimşir Zararlısına Dur Diyoruz. https://artvinobm.ogm.gov.tr/ Site Pages/ OGM/ OGM Haberler.aspx? Erişim tarihi: 28.11.2018.

Clausen, C.P. (1978). Introduced parasites and predators of arthropod pests and weeds: a review (In: Agricultural Hand Book, U.S. Dept. of Agriculture) Washington, D.C., USA.

Feldtrauer, J.F., Feldtrauer, J.J. \& Brua, C. (2009). Premiers signalements en France de la Pyrale du Buis Diaphania perspectalis (Walker,
1859), espece exotique envahissante s'attaquant aux Buis (Lepidoptera, Crambidae). Bulletin de la Societe entomologique de Mulhouse, 65, 55-58.

Fischbein, D. \& Corley, J.C. (2015). Classical biological control of an invasive forest pest: a world perspective of the management of Sirex noctilio using the parasitoid Ibalia leucospoides (Hymenoptera: Ibaliidae). Bulletin of Entomological Research, 105(1), 112.

Fora, C.G. \& Poşta, D.S. (2015). Cydalima perspectalis Walk. (Lepidoptera: Crambidae), a dangerous pest of Buxus sempervirens in Timis County, Romania. Journal of Horticulture, Forestry and Biotechnology, 19 (3), 26-31.

Grégoire, J.C. (1988). The greater European spruce beetle (Editor Berryman A.A. In: Dynamics of Forest Insects Populations) New York, USA: Plenum Press, 455-478.

Gninenko, Y.I., Shiryaeva, N.V. \& Shurov V.I. (2014). The box tree moth - a new invasive pest 
in the Caucasian forests. Plant Health Research and Practice, 7, 32-39.

Henricot, B. \& Culham, A., (2002). Cylindrocladium buxicola, a new species affecting Buxus spp., and its phylogenetic status. Mycologia, 94, 980-997.

Hizal, E., Köse, M., Yesil, C. \& Kaynar, D. (2012). The new pest Cydalima perspectalis (Walker, 1859) (Lepidoptera: Crambidae) in Turkey. Journal of Animal and Veterinary Advances, 11(3), 400-403.

Inoue, H., Sugi, S., Kuroko, H., Moriuti, S. \& Kawabe A. (1982). Pyralidae (Editors Inoue H., Sugi S., Kuroko H., Moriuti S., Kawabe A. In: Moths of Japan) Kodansha, pp. 307-404, Tokyo, Japan.

John, R. \& Schumacher, J. (2013). Der Buchsbaum-Zünsler (Cydalima perspectalis) im Grenzach-Wyhlener Buchswald Invasionschronik und Monitoringergebnisse. (Der Buchsbaum-Zünsler (Cydalima perspectalis) im Grenzach-Wyhlener Buchswald - Invasionschronik und Monitoringergebnisse.). Gesunde Pflanzen, 65, 1-6.

Kenis, M., Nacambo, S., Leuthardt, F.L.G., Di Domenico, F. \& Haye, T. (2013). The box tree moth, Cydalima perspectalis, in Europe: horticultural pest or environmental disaster? Aliens, 33, 38-41.

Krüger, E.O. (2008). Glyphodes perspectalis (Walker, 1859) - new for the European fauna (Lepidoptera: Crambidae). Entomologische Zeitschrift mit Insekten-Börse, 118(2), 81-83.

Lehtijärvi, A., Doğmuş-Lehtijärvi, H.T. \& Oskay, F. (2014). Cylindrocladium buxicola is threatening the native Buxus sempervirens populations in Turkey. Plant Protection Science, 50(4), 227-229.

Lehtijärvi, A., Doğmuş-Lehtijärvi, H.T. \& Oskay, F. (2017). Boxwood Blight in Turkey: Impact on Natural Boxwood Populations and Management Challenges. Baltic Forestry, 23(1), 274-278.

Leuthardt, F.L.G.\& Baur, B. (2013). Oviposition preference and larval development of the invasive moth Cydalima perspectalis on five European box-tree varieties. Journal of Applied Entomology, 137, 437-444.

Leuthardt, F.L.G., Billen, W.\& Baur, B. (2010). Spread of the box-tree pyralid Diaphania perspectalis (Lepidoptera: Pyralidae) in the region of Basel - a pest species new for Switzerland. (Ausbreitung des Buchsbaumzünslers Diaphania perspectalis (Lepidoptera, Pyralidae) in der Region Basel eine für die Schweiz neue Schädlingsart.). Entomo Helvetica, 3, 51-57.
Leuthardt, F.L.G. \& Ramin S. (2011). The BoxTree Pyralid Diaphania perspectalis Occurrence, Dispersal and Impact of an Invasive Species in Switzerland. Jahrbuch der Baumpflege, 255-260.

Öztürk, N., Akbulut, S. \& Yüksel, B. (2016). Düzce İçin Yeni Bir Zararlı Cydalima perspectalis (Walker, 1859) (Lepidoptera: Crambidae). Ormancllık Dergisi, 12(1), 112121.

Sáfián, S. \& Horváth, B. (2011). Box tree moth (Cydalima perspectalis (Walker, 1859)) - a potential garden pest - new member in the Hungarian lepidoptera fauna (Lepidoptera: Crambidae). Növényvédelem, 47(10), 437-438.

Seljak, G. (2012). Six new alien phytophagous insect species recorded in Slovenia in 2011. Acta Entomologica Slovenica, 20(1), 31-44.

Straten, M.J. van der \& Muus, T.S.T. (2010). The box tree pyralid, Glyphodes perspectalis (Lepidoptera: Crambidae), an invasive alien moth ruining box trees. Proceedings of the Netherlands Entomological Society, 21, 107111.

Toper-Kaygın, A. \& Taşdeler, C. (2018). Cydalima perspectalis (Walker) (Lepidoptera: Crambidae) Şimşirlerimiz İçin Bir Tehdit mi? III. Türkiye Orman Entomolojisi ve Patolojisi Sempozyumu Bildiri Özetleri, 10-12 Mayıs 2018, Artvin, p. 21.

Wan, H., Haye, T., Kenis, M., Nacambo, S., Xu, H., Zhang, F. \& Li, H. (2014). Biology and natural enemies of Cydalima perspectalis in Asia: Is there biological control potential in Europe? Journal of Applied Entomology, 138(10), 715-722.

Yaltırık, F. \& Efe, A. (2000). Dendroloji. İstanbul Üniversitesi Orman Fakültesi Yayınları No: 4265/465, ISBN: 975-404-594-1. 